\title{
Unklare Schmerzen im Bauch Non-specific abdominal pain
}

\author{
Bauchschmerzen klingen banal, sind für den Rettungsdienst aber \\ alles andere als einfach. Häufig gelingt es nur, eine Verdachts- \\ diagnose zu stellen. Entscheidend ist, die Transportpriorität \\ festzulegen und die richtige Zielklinik auszuwählen.
}

Rico Kuhnke • Stephen Dodds

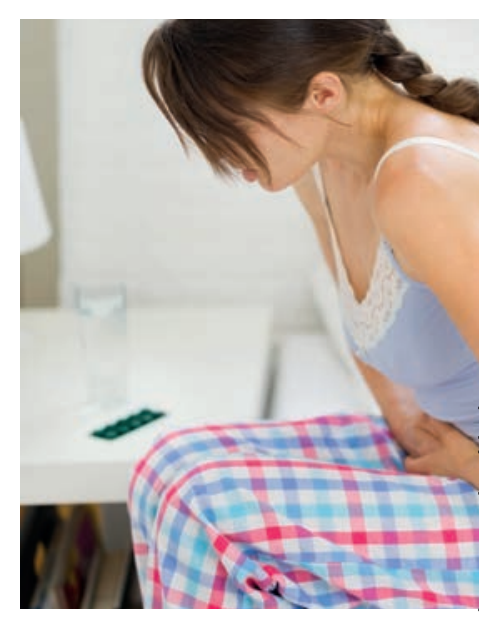

Emergency call „Where has Thomas gone on holiday then?“ Anton Moser, an older, experienced colleague, asks Claudia Gerold. „He's paragliding in South Tyrol. Totally nuts if you ask me, but he seems to like it." While they are talking about Thomas's hobby, they get the next emergency call. „Lupinenweg 8, Family Steinhoff, 32-year-old female patient with abdominal pain.“

Situation at the scene The Steinhoff family live in a new housing estate on the outskirts of the town. The husband is already waiting on the street as they arrive. He explains that his wife has been complaining of abdominal pain since yesterday. The pain got worse throughout the day, and although it improved for a short time, it has now become unbearable. Claudia calms the husband down and hurries to the patient with Anton.

Relieving posture and hard abdomen As soon as they enter the bedroom, they notice the relieving posture of the young woman. She is pale and is moaning with pain. While Claudia checks over her vital signs, Anton prepares some oxygen and an IV infusion. Mrs Steinhoff's pulse is palpable, but at 140 beats per minute is tachycardic. The patient is breathing quickly, but deeply enough. Even before they take the patient's history, Claudia asks her colleague to call for the emergency doctor.

Patient history Claudia quickly takes the patient's history. For orientation she uses the SAMPLER+S mnemonic. Although the questions about allergies, medication and previous conditions don't reveal anything, Claudia's ears prick up at the last point: „Mrs Steinhoff, is it possible that you could be pregnant?" The patient replies that she takes the pill, but that her period is 5 weeks overdue. Because of the stress of moving into their new house, she just hadn't thought about it. Meanwhile the team have put in a large-bore IV line, and are administering the infusion quickly. The patient's blood pressure is a little low at $100 / 70 \mathrm{mmHg}$, but not un-
Einsatzmeldung „Wo genießt eigentlich Thomas seinen Urlaub?“, fragt Anton Moser, ein älterer, erfahrener Kollege, Claudia Gerold. „Thomas ist Gleitschirmfliegen in Südtirol. Völlig abgefahren, wenn Du mich fragst. Aber ihm scheint es zu gefallen." Während sich die beiden noch über das Hobby von Thomas unterhalten, bekommen sie einen Folgeauftrag: „Lupinenweg 8, Familie Steinhoff, 32jährige Patientin, unklares Abdomen, Anfahrt ohne Sonderrechte.“

Situation vor Ort Familie Steinhoff wohnt in einer Neubausiedlung am Stadtrand. Auf der Straße wartet bereits der Ehemann. Er schildert, dass seine Frau seit gestern über Bauchschmerzen klage. Über den Tag hätten die Schmerzen zugenommen, nach einer kurzen Besserung seien sie jetzt unerträglich stark. Claudia beruhigt den Ehemann und geht mit Anton rasch zu der Patientin.

Schonhaltung und brettharte Bauchdecke Schon beim Eintreten ins Schlafzimmer fällt die gekrümmte Haltung der jungen Frau auf. Sie ist bleich und stöhnt vor Schmerzen. Während sich Claudia einen Überblick über die Vitalparameter verschafft, bereitet Anton Sauerstoff und eine Infusion vor. Der Puls von Frau Steinhoff ist gut tastbar, aber mit 140 Schlägen pro Minute tachykard. Die Patientin atmet schnell, aber tief genug. Noch vor der Anamneseerhebung bittet Claudia ihren Kollegen, einen Notarzt nachzufordern.

Anamnese Zügig erhebt Claudia die Anamnese. Dabei orientiert sie sich am SAMPLER+S-Schema. Während die Fragen nach Allergien, Medikamenten und Vorerkrankungen keine Auffälligkeiten ergeben, wird Claudia beim letzten Punkt hellhörig. „Frau Steinhoff, könnten Sie schwanger sein?“, fragt sie. Sie nehme zwar die Pille, antwortet die Patientin, aber die Regelblutung sei seit 5 Wochen überfällig. Durch den Stress beim Umzug in das neue Haus habe sie das ganz verdrängt. Mittlerweile hat das Team einen großlumigen venösen Zugang gelegt und lässt die Infusion zügig laufen. Der Blutdruck ist mit 100/70 mmHg zwar niedrig, aber für die schlanke 
usual for a slim woman. „Anton, can you get everything ready for an urgent transfer to the hospital, please?" asks Claudia, who looks very serious.

Pain assessment To better understand the symptoms, Claudia uses the OPQRST system. She asks specifically when the pain began (Onset), if anything makes the pain worse or better (Provocation/Palliation), what kind of pain it is - is it dull, stabbing or throbbing (Quality), if it moves (Radiation), how strong it is (Severity), and finally how the pain has developed over time (Time). The patient explains that the pain started in her lower abdomen, on the left. At the beginning it was more of a pulling pain, but then the pain suddenly increased and radiated to the back and upper abdomen. Just before the ambulance arrived the pain was devastating. Now it is more bearable but still very strong. On a scale from 1-10, the patient rates her pain at 7 .

Suspected diagnosis and transfer to the hospital Anton returns with the roll-in stretcher. „I think we are dealing with an ectopic pregnancy with a tubal rupture. Let's not waste any time, and let's get her transferred to the hospital quickly," says Claudia. Although everything goes very quickly, she still finds time to explain the suspected diagnosis in basic terms to the couple, and tries to reassure them. As they are loading the roll-in stretcher to the ambulance the emergency doctor arrives. Claudia describes the case. The doctor nods and during the journey to the hospital the patient is given sufficient pain relief. Additionally, Anton has informed the central clinic that they will be arriving at the intensive care unit soon.

Debriefing On the way back from the hospital, Anton asks his colleague: „Hey, how did you come up with that suspected diagnosis so quickly?“ „I make it easy for myself, and use mnemonics like SAMPLER+S, or the OPQRST system for pain assessment." Anton is impressed, and asks her to explain the mnemonics to him on the journey back.
Frau noch nicht außergewöhnlich. „Anton, mach doch bitte alles für einen raschen Transport in die Klinik fertig“, bittet Claudia ihren Kollegen und wirkt dabei sehr ernst.

Schmerzdiagnose Um die Symptomatik besser zu erfassen, nutzt Claudia das OPQRST-Schema: Sie fragt gezielt, wann die Schmerzen begonnen haben (Onset), was den Schmerz auslöst oder bessert (Provocation / Palliation), ob der Schmerz eher dumpf, stechend oder pochend ist (Quality), ob er ausstrahlt (Radiation), wie stark er ist (Severity) und wie er sich über die Zeit entwickelt hat (Time). Die Patientin schildert, dass die Schmerzen im linken Unterbauch begonnen hätten. Anfangs seien sie eher ziehend gewesen, dann hätten die Schmerzen plötzlich zugenommen und in Rücken und Oberbauch ausgestrahlt. Kurz vor Eintreffen des Rettungsdienstes sei der Schmerz vernichtend gewesen. Nun sei es zwar erträglich, aber immer noch sehr stark. Auf einer Skala von 1-10 gibt die Patientin den Schmerz mit 7 an.

Verdachtsdiagnose und Transport in die Klinik Anton ist mittlerweile mit der Fahrtrage zurück. „Ich denke, wir haben es mit einer extrauterinen Gravidität mit Tubaruptur zu tun. Lass uns keine Zeit verlieren und uns mit dem Transport beeilen“, sagt Claudia. Obwohl nun alles sehr schnell geht, findet sie die Zeit, dem Ehepaar die Verdachtsdiagnose mit einfachen Worten zu erläutern und beruhigend einzuwirken. Beim Einladen der Trage in das Fahrzeug trifft der Notarzt ein. Claudia schildert kurz den Fall. Der Arzt nickt, und die Patientin erhält noch auf der Fahrt eine ausreichende Analgesie. Unterdessen hat Anton das Zentralklinikum verständigt und das baldige Eintreffen im Schockraum angekündigt.

Nachbesprechung Bei der Rückfahrt fragt Anton seine Kollegin: „Sag mal, wie bist Du denn so schnell auf die Verdachtsdiagnose gekommen?“ „Ich mach es mir einfach und orientiere mich an Merkhilfen, wie zum Beispiel SAMPLER+S oder dem OPQRST-Schema zur Schmerzdiagnose." Anton ist beeindruckt und lässt sich auf der Rückfahrt die Schemata erläutern.

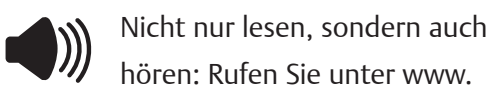

thieme-connect.de/products die Seite von retten! auf. Dort finden Sie den englischen Podcast zum Text. Zum Podcast gelangen Sie auch über den nebenstehenden QR-Code.

\section{vocabulary}

abdominal pain

pregnancy

period/menstruation

dull

stabbing

throbbing

mnemonic

\section{Vokabeln}

Bauchschmerzen

Schwangerschaft

Regelblutung

dumpf

stechend

pochend

Merkhilfe/Eselsbrücke 